\title{
Optimasi Rasio Air dan Karbon Berpori untuk Proses Pembentukan Metana Hidrat
}

\author{
Wibiana Wulan Nandari ${ }^{\mathrm{a}^{*}}$, Imam Prasetyo ${ }^{\mathrm{b}}$, and Moh. Fahrurrozi ${ }^{\mathrm{b}}$
}

aProgram Studi S1 Teknik Kimia, Fakultas Teknologi Industri, Universitas Pembangunan Nasional "Veteran" Yogyakarta Jln. SWK 104 (Lingkar Utara), Condongcatur, Yogyakarta, 55283, Indonesia

burusan Teknik Kimia, Fakultas Teknik, Universitas Gadjah Mada Yogyakarta

Jln. Grafika 2, Kampus UGM, Yogyakarta, 55281, Indonesia

\section{Artikel histori :}

Diterima 20 Februari 2016 Diterima dalam revisi 25 Februari 2016 Diterima 4 Mei 2016 Online 1 Juni 2016

\begin{abstract}
ABSTRAK: Metana merupakan sumber energi alternatif yang sangat potensial dan melimpah serta menghasilkan emisi $\mathrm{CO}_{2}$ yang lebih rendah ketika digunakan sebagai bahan bakar karena kandungan $\mathrm{C}$ dalam molekul metana jauh lebih kecil dari kandungan $\mathrm{H}$ nya. Selain ada dalam bentuk gas, metana di alam juga bisa berada dalam bentuk metana hidrat. Setiap volume metana hidrat mengandung sebanyak 164 volume gas metana dalam keadaan standar (STP). Proses terbentuknya metana hidrat di alam dapat diadopsi sebagai metode penyimpanan gas metana. Pada penelitian ini akan dilakukan percobaan pembentukan metana hidrat pada karbon mesopori dengan jumlah air yang bervariasi untuk mengetahui kandungan air optimum untuk membentuk metana hidrat secara efektif. Penelitian dilakukan dengan mengadsorpsi gas metana pada karbon berpori yang basah dengan metode static volumetric. Untuk mengetahui rasio yang optimum terhadap proses terbentuknya metana hidrat, maka pada penelitian ini dilakukan percobaan dengan rasio berat air dibandingkan karbon berpori 0,$5 ; 1$; 1,5; 2. Sistem adsorpsi dikondisikan pada suhu $275 \mathrm{~K}$ dengan maksud untuk menghindari terbentuknya es (sistem dikondisikan diatas titik beku air). Hasil percobaan menunjukkan bahwa rasio air : karbon mesopori yang memberikan jumlah metana hidrat yang paling besar adalah pada $\mathrm{R}=1$
\end{abstract}

Kata Kunci: Penyimpanan metana, Metana Hidrat, Rasio Air-Karbon Mesopori

\begin{abstract}
Methane is a potential alternative energy source which is abundant and produces lower $\mathrm{CO}_{2}$ emissions when it is used as fuel due to the content of $\mathrm{C}$ in the methane molecule is much lesser than its $\mathrm{H}$ content. Besides in a form of gas, methane in nature can also be in the form of methane hydrates. The formation process of methane hydrates in nature can be adopted as a method of methane storage. In this study, methane hydrate was formed on mesopore carbon with weight ratio of water and porous carbon 0,$5 ; 1 ; 1,5 ; 2$. Adsorption system was conditioned at the temperature $275 \mathrm{~K}$. Methane gas was injected into the clean vacuum system, at various pressures. The adsorption equilibrium was Indicated by stable pressure in the adsorption system. Moles of adsorbed methane was calculated from the difference of mole before and after adsorption. The Pressure of methane hydrate formed can be measured from the point of the number of moles from methane adsorbed which increased significantly. The experimental resulted that the weight ratio of water and porous carbon as 1:1 gave optimum methane hydrates formation.
\end{abstract}

Keywords : Methane Storage, Methane Hydrate, Water-Carbon Ratio

\section{Pendahuluan}

Gas Hidrat adalah suatu padatan menyerupai es yang terbentuk dari molekul air yang berikatan hidrogen membentuk sangkar (host molecule) dan molekul gas (biasanya metana) sebagai guest molecule yang terperangkap di dalam sangkar air tersebut. Di alam, cadangan gas hidrat berada di dalam sedimen lautan dalam jumlah yang sangat besar yang sebagian besar terdiri dari metana hidrat sehingga metana hidrat sangat potensial untuk dikembangkan sebagai energi alternatif menggantikan bahan bakar minyak (Sloan, 2008). Di

${ }^{*}$ Corresponding Author: +62 85642449292

Email: wibianawulan@mail.com 
samping jumlah cadangannya yang berlimpah, metana memiliki bilangan oktan yang lebih tinggi dan secara inheren lebih ramah lingkungan sebagai bahan bakar karena emisi $\mathrm{CO}_{2}$ yang lebih sedikit (rasio $\mathrm{C} / \mathrm{H}$ dalam molekul metana lebih kecil dibandingkan hidrokarbon yang lain).

Metana hidrat stabil pada temperatur rendah dan tekanan tinggi. Untuk 1 meter kubik gas hidrat akan melepaskan $164 \mathrm{~m}^{3}$ gas alam/ metana pada suhu $25^{\circ} \mathrm{C}$ dan tekanan 1 atm (suhu dan tekanan udara bebas), sehingga diperkirakan cadangan energi tersebut tidak akan habis dalam kurun waktu 800 tahun (Soesilo, 2008). Dalam $1 \mathrm{~m}^{3}$ metana hidrat ini, volume yang ditempati oleh metana sebesar $0,2 \mathrm{~m}^{3}$, sedangkan sisanya sebesar $0,8 \mathrm{~m}^{3}$ terisi oleh air (Makogon et al., 2007).

Salah satu kendala dalam pemanfaatan gas alam sebagai bahan bakar adalah keterkaitan dengan sifatnya sebagai gas superkritis yang sukar untuk dicairkan. Oleh karena itu dalam pemanfaatannya gas metana biasanya disimpan pada suhu kamar dengan tekanan yang sangat tinggi yaitu pada kisaran 200-250 bar (Compressed Natural Gas atau CNG) sehingga membutuhkan biaya tinggi untuk pembuatan bejana yang tebal dan untuk kompresinya (multi-stage compression). Metode penyimpanan gas alam lainnya adalah dengan sistem refrigerasi pada suhu di bawah $-162^{\circ} \mathrm{C}$ sehingga gas alam tersimpan sebagai Liquified Natural Gas (LNG) dengan biaya refrigerasi yang cukup mahal. Metode yang saat ini mulai dikembangkan adalah menyimpan gas metana dalam kondisi terhidrat (suhu $2{ }^{\circ} \mathrm{C}$, tekanan 35 bar). Metode ini mengadopsi proses terbentuknya metana hidrat yang ada di alam. Dengan suhu yang tidak terlalu rendah dan tekanan tidak terlalu tinggi dibandingkan dengan metode sebelumnya, sehingga cara penyimpanan dalam bentuk terhidrat ini relatif lebih aman dan lebih murah.

Untuk meningkatkan jumlah metana hidrat yang terbentuk diperlukan media yang memberikan luas kontak yang besar untuk memfasilitasi bergabungnya molekul air dan molekul metana dalam membentuk hidrat (Dai,2009; Prasetyo et al., 2011). Karbon berpori menjadi salah satu material yang menarik sebagai media penyimpanan metana karena karbon berpori memiliki luas permukaan internal yang besar, sebagai alat penjerap, dan harga yang rendah (Talu, 1992). Selain itu karbon berpori memiliki kelebihan diantaranya bersifat sangat hydrophobic, tahan terhadap lingkungan yang asam maupun basa, dan strukturnya stabil pada suhu tinggi dan memiliki karakteristik permukaan yang bersifat non polar (Yang,2003).

Penelitian yang dilakukan oleh Yunanto (2012) menunjukkan bahwa kapasitas penjerapan metana pada karbon berpori basah (dalam bentuk hidrat) jauh lebih besar dibandingkan dengan karbon berpori kering. Sifat karbon berpori yang hydrophobic sangat menguntungkan dalam pembentukan metana hidrat. Hal ini karena air tidak membasahi permukaan, tetapi air membentuk droplet sehingga memperluas kontak bidang antar air dan gas metana. Semakin besar luas permukaan kontak maka semakin banyak metana hidrat yang terbentuk. Kehadiran bahan berpori memang diperlukan dalam pembentukan hidrat, karena untuk membentuk hidrat langsung dari gas $\mathrm{CH}_{4}$ sangat sulit. Hal ini disebabkan oleh kelarutan metana dalam air sangat rendah, sedangkan struktur kristal khas (klatrat) hidrat yang terbuat dari molekul air yang saling berikatan menggunakan ikatan hidrogen. Penyebaran air di permukaan karbon berpori memudahkan molekul air untuk kontak langsung dengan molekul gas $\mathrm{CH}_{4}$ dibandingkan tanpa kehadiran material berpori (Zhou et al., 2004).

Pada penelitian ini, akan dicari rasio air dan karbon aktif yang mampu membentuk metana hidrat pada media karbon berpori optimum.

\section{Metode Penelitian}

\subsection{Bahan Penelitian}

Bahan yang digunakan dalam penelitian ini adalah gas $\mathrm{CH}_{4}$ dengan kadar 99,9\%, aqua demin, dan karbon berpori yang dihasilkan dari pirolisis bahan polimer yang disintesis dari resorcinol fenol formaldehid dan etilen glikol (dinamakan RPF-EG2).

\subsection{Alat Penelitian}

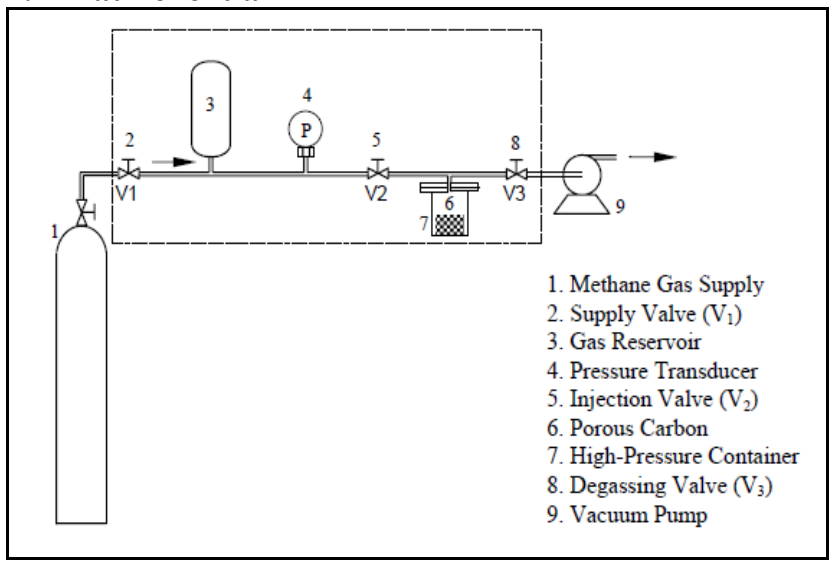

Gambar 1. Skema Alat Percobaan Pembentukan Metana Hidrat

\subsection{Prosedur Penelitian}

Rangkaian alat percobaan pembentukan metana hidrat dalam media karbon berpori ditunjukkan dalam Gambar 1 . Rangkaian alat ini pada prisipnya merupakan alat adsorpsi secara statik volumetrik yang dirangkai menggunakan Ultra High Vacuum Fitting and Valve tipe $\mathrm{VCR}^{\circledR}$. Sebelum percobaan dimulai sejumlah karbon diletakan dalam sample cell kemudian dilakukan proses degassing untuk menghilangkan kontaminan dan uap air di dalam sistem. Kemudian karbon berpori dikeluarkan dari sample cell untuk kemudian ditimbang. Selanjutnya karbon berpori tersebut dimasukkan ke sample cell dan ditambahkan air (demineralized water) dengan perbandingan rasio berat air dibandingkan dengan berat karbon berpori adalah 0,$5 ; 1$; 1,$5 ; 2$. 
Tahap kedua adalah adsorpsi gas metana pada karbon berpori dengan metode static volumetric. Sistem adsorpsi dikondisikan pada suhu $275 \mathrm{~K}$ dengan maksud untuk menghindari terbentuknya es (sistem dikondisikan diatas titik beku air). Dengan menginjeksikan gas metana dalam berbagai tekanan dalam sistem adsorpsi akan diperoleh data kesetimbangan adsorpsi. Kesetimbangan adsorpsi ditunjukkan dengan stabilnya tekanan di dalam sistem adsorpsi, biasanya bervariasi dari 10 menit hingga 120 menit.

Langkah-langkah untuk melakukan uji adsorpsi gas secara volumetrik adalah dengan menyetel regulator sesuai dengan tekanan maksimum yang akan digunakan dalam pengujian, memastikan pompa vakum bekerja dengan baik dan sistem adsorpsi telah vakum $0 \mathrm{MPa}$ absolut, serta tidak ada kebocoran. Setelah itu memastikan bahwa valve $\mathrm{V}_{2}$ dan $\mathrm{V}_{3}$ telah tertutup serta valve nomor $\mathrm{V}_{1}$ dalam keadaan terbuka. Untuk mengisi loading cell (tekanan injeksi), valve no $\mathrm{V}_{1}$ dibuka secara perlahan hingga dicapai tekanan yang diinginkan $\left(\mathrm{P}_{1}\right)$, lalu ditutup kembali. Selanjutnya untuk melakukan proses adsorpsi, valve no. $\mathrm{V}_{2}$ dibuka dan diamati penurunan tekanan di PT hingga diperoleh tekanan dalam keadaan setimbang $\left(\mathrm{P}_{2}\right)$. Untuk melanjutkan pada titik kesetimbangan berikutnya, valve no. $\mathrm{V}_{2}$ ditutup kembali dan langkah-langkah tersebut diulangi sampai tekanan maksimal yang mampu dioperasikan (4,0 MPa).

Untuk menghitung jumlah mol terjerap pada saat kesetimbangan dapat dilakukan dengan menggunakan persamaan berikut :

$$
n_{a d s}=\frac{P_{1} V_{1}}{z R T}-\frac{P_{2} V_{2}}{z R T}
$$

\section{Hasil dan Pembahasan}

\section{Menentukan Rasio Air dan Karbon Berpori yang Optimum untuk Pembentukan Metana Hidrat}

Rasio aquadest : berat karbon berpori (R) berpengaruh terhadap titik ter-bentuknya metana hidrat. Untuk mengetahui rasio yang optimum terhadap proses terbentuknya metana hidrat, maka pada penelitian ini dilakukan percobaan dengan rasio berat air dibandingkan karbon berpori 0,$5 ; 1 ; 1,5 ; 2$. Sistem adsorpsi dikondisikan pada suhu $275 \mathrm{~K}$ dengan maksud untuk menghindari terbentuknya es (sistem dikondisikan diatas titik beku air).

Pada Gambar 2 terlihat bahwa rasio air : karbon mesopori yang memberikan jumlah metana hidrat yang paling besar adalah pada $\mathrm{R}=1$. Pada tekanan di bawah 3,16 $\mathrm{MPa}$, gas metana terlarut dalam air. Setelah tekanan dan temperatur memenuhi syarat terbentuknya hidrat (pada percobaan ini tekanan 31,6 MPa), gas metana yang terjerap naik secara signifikan. Hal ini menunjukkan bahwa pada titik tersebut metana hidrat terbentuk. Dengan mengingat bahwa syarat terbentuknya metana hidrat menurut Carroll (2009) ada tiga, yaitu ada guest molekul (gas metana), ada host molekul (air yang cukup), dan kondisi operasi yang memenuhi (terkait temperatur dan suhu), maka dapat disimpulkan bahwa dengan pada rasio $\mathrm{R}=1$, jumlah air efektif untuk membentuk hidrat.

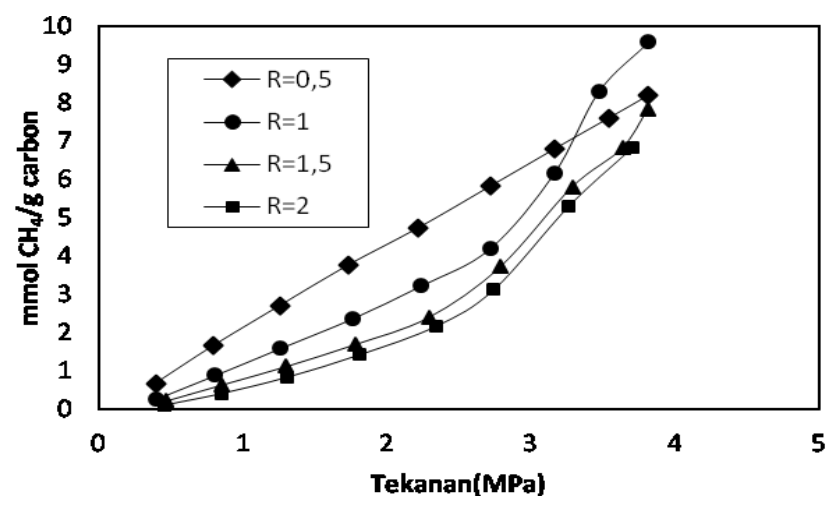

Gambar 2. Pengaruh Jumlah Air pada Proses Pembentukan Metana Hidrat

Untuk percobaan dengan rasio $\mathrm{R}=0,5$; kurva hanya terlihat lurus serta tidak ada kenaikan jumlah gas metana yang terjerap. Hal ini menunjukkan bahwa tidak ada fenomena metana hidrat yang terbentuk. Jumlah air yang setengah kali berat karbon berpori ini dapat disimpulkan tidak mencukupi untuk membentuk metana hidrat. Sedangkan untuk rasio $\mathrm{R}=1,5$ dan $\mathrm{R}=2$, metana hidrat terbentuk lebih sedikit daripada percobaan pada $\mathrm{R}=1$, dan tekanan terbentuknya hidrat yang lebih tinggi, yaitu pada tekanan yang lebih tinggi. Hal ini disebabkan karena jumlah air yang lebih banyak justru menutupi pori-pori karbon mesopori, sehingga luas kontak antara air dan gas metana jauh lebih sedikit jika dibandingkan kontak terjadi pada permukaan pori karbon.

Penambahan air dalam proses adsorpsi gas metana pada media karbon berpori meningkatkan kapasitas penjerapan metana dalam keadaan terhidrat. Penelitian sebelumnya yang dilakukan oleh Yunanto (2012) telah membandingkan adsorpsi gas metana menggunakan karbon mesopori kering dan karbon mesopori basah.

Dari Gambar 3, terlihat jelas bahwa pada tekanan 0 3.0 Mpa, karbon mesopori basah tidak dapat mengadsorpsi gas $\mathrm{CH}_{4}$ namun nilai kapasitas penjerapannya meningkat tajam pada rentang tekanan 3,0-4,0 $\mathrm{MPa}$. Keadaan ini terjadi karena pada tekanan $0-3,0 \mathrm{MPa}$ hanya terjadi physisorption yang jumlahnya sangat kecil dikarenakan molekul gas $\mathrm{CH}_{4}$ tidak dapat menerobos ke dalam saluran mesopori karena kehadiran molekul air yang menutup transport channel (Celzard et al, 2005). Sedangkan pada tekanan lebih besar dari 3,0 $\mathrm{MPa}$, metana hidrat mulai terbentuk karena semua syarat terbentuknya gas hidrat telah terpenuhi, sehingga jumlah molekul gas $\mathrm{CH}_{4}$ yang terjerap meningkat secara tajam. Dibandingkan dengan karbon MS2 kering, kapasitas penjerapan gas $\mathrm{CH}_{4}$ dalam keadaan terhidrat jauh lebih besar. Pada tekanan \pm 4,0 $\mathrm{MPa}$ gas $\mathrm{CH}_{4}$ yang terjerap dalam keadaan terhidrat bernilai 15,7 $\mathrm{mmol} / \mathrm{g}$. Nilai ini hampir dua kali lebih besar daripada nilai penjerapan oleh karbon MS2 dalam keadaan kering. 


\section{Daftar Pustaka}

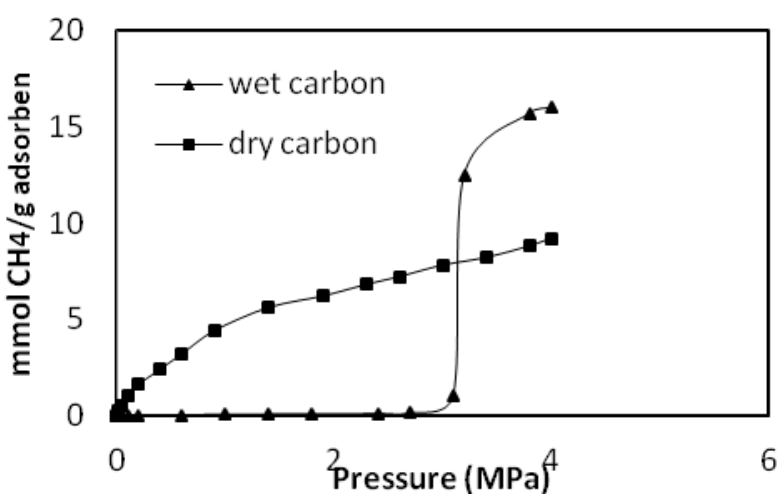

Gambar 3. Perbandingan Isoterm Adsorpsi Gas $\mathrm{CH}_{4}$ menggunakan Karbon Mesopori Basah dan KarbonMesopori Kering (Yunanto, 2012)

Rasio air optimum yang diperoleh menguatkan penelitian yang dilakukan oleh Celzard pada tahun 2006. Hasil penelitian menunjukkan bahwa perbandingan air dan karbon mesopori yang optimum untuk pembentukan metana hidrat adalah mendekati 1.

\section{Kesimpulan}

Kesimpulan yang dapat diambil dari penelitian ini adalah dinding pori yang bersifat hidrofobik dari material karbon berpori memicu terbentuknya metana hidrat jika dimensi porinya sesuai dengan ukuran metana hidrat. Dalam penelitian ini karbon berpori yang digunakan adalah karbon mesopori. Untuk membentuk metana hidrat diperlukan sejumlah air dalam media karbon berpori. Perbandingan air dan karbon berpori yang mampu menghasilkan metana hidrat paling besar adalah pada perbandingan 1:1.
Carrol, John, 2009, Natural Gas Hydrates, Elsevier's Science and Technology Rights Department in Oxfords

Celzard, A., Mareche, J.F., 2005, Optimal Wetting of Active Carbons for Methane Hydrate Formation, University Henry Poincare-Nancy, France

Dai, X.D., Liu, X.M., Xing, W., Qian, L., Qiao, K., Yan, Z.F., 2009, Natural Gas Storage on Activated Carbon Nodified by Metal Oxides, J Porous Mater, vol.16, pp.27-32

Makogon, Y.F., Holditch, S.A. and Makogon, T.Y., 2007, Natural gas Hydrate-A Potential Energy Source for $21^{\text {th }}$ Century, Journal Petrolleum Science and Engineering. Vol. 56, No. 1-3: 14-31.

Prasetyo, I., Budhijanto, Rochmadi, Yunanto, R., Ariyanto, T., 2011, Methane Storage by Methane Hydrate Formation Within Water-Saturated Porous Carbon, Conference Chemeca2011, New South Wales, 18-21 September 2011.

Sloan, E.D., Koh, C.A., 2008, Chlatrate Hydrates of Nautral Gases, 3rd Edition, Taylor and Francis Group, USA

Talu, O., 1992, An Overview of Adsorptive Storage of Natural Gas, Fundamentals of Adsorption, Proc. $4^{\text {th }}$ Int. Conf. On Fundamentals of Adsorption, Kyoto, May 17-22, pp.655-662

Yang, R.T., 2003, Adsorbent Fundamentals and Applications, University of Michigan, Michigan.

Yunanto, R., 2012, Penjerapan Gas Rumah Kaca dengan Menggunakan Berbagai Karbon Berpori, Laporan Thesis, Universitas Gadjah Mada, Yogyakarta

Zhou, Y.P., Dai, M., Zhou, L.,2004, Storage of Methane on wet activated carbon: Influence of pore size distribution. Carbon 42(s 8-9): 1855-1858. 